\title{
Correlates of Child Labour and Poverty Alleviation among Low-Income Earners in Kwara State, Nigeria
}

\author{
Kadiri, Ismaila Bolarinwa \\ Department of Industrial Relations and Personnel Management \\ University of Ilorin, Ilorin, Nigeria \\ Oloyede, Najeeb Babatunde ${ }^{2}$ \\ Department of Library \\ Summit University, Offa, Nigeria \\ Dunmade, Emmanuel Olaniyi ${ }^{3}$ \\ Department of Industrial Relations and Personnel Management \\ University of Ilorin, Ilorin, Nigeria \\ Aliyu, Mustapha Olanrewaju ${ }^{4}$ \\ Department of Industrial Relations and Personnel Management \\ University of Ilorin, Ilorin, Nigeria \\ Olowoleni, Folaranmi Modupe ${ }^{5}$ \\ Registry Department \\ University of Ilorin, Ilorin, Nigeria
}

\begin{abstract}
The study explores the correlations between child labour and poverty alleviation among the low-income earners in Kwara State, Nigeria. Survey design and purposive sampling method were employed to select the respondents from the 3 Senatorial districts of Kwara state. The Chi-square $\left(X^{2}\right.$ ) method of data analyses then used to analyze the data obtained. The result is a $2 \times 2$ table is taken a degree of freedom of $(r-1)(k-1)=1$ at $5 \%$ level of significance, $X^{2}{ }_{t}=3.84$ and $X^{2}{ }_{c}=0.17$. Since the $X^{2}{ }_{t}>X^{2}{ }_{c}$, it shows that $a$ relationship exists between child labour and poverty reduction in Kwara state. The study concluded that governments, at the federal and state levels, are yet to live up to their expectations. Their inability to provide jobs for graduates have discouraged most of the children to have an interest in schooling. Therefore, the government should provide a potent economic environment that will encourage those with genuine ideas to engage in promising economic activities. This will lift a lot of low-income earners to higher pedigree. Similarly, parent/guardians in the low-income groups should be encouraged that extra efforts in assisting their children not to engage in child labour but schooling as a future investment with a higher rate of return.
\end{abstract}

Keywords: Child labour, Poverty alleviation, Low-income earners, Senatorial Districts, Kwara State.

JEL Classification: J01

\section{INTRODUCTION}

Child abuse and violence have continued to show its ugly face, particularly in the Third World countries. It has come in different ways such as domestic, sexual abuse and Child labour. This situation has continued to grow at alarming rates, which has led to a loss of lives, insecurity, and economic loss, among others (Heise et al. 2008). The situation is the same in the country. Despite the ratification of international conventions by Nigeria on Labour, the country has continued to witness the engagement of its child in the worst forms of Child Labor. 
This is common in the areas of commercial sex exploitation, armed banditry, Fishing and farming, street trading, housekeeping, quarrying and other forms of activities.

Despite the inherent nature of these hazardous activities, these children were continually exposed to, and there is often a thin line between what is Child work and Child Labor. Scholars have a divergent view in defining what child labour is all about (AdontengKissi,2018). The international labour organizations (ILO, 2002) came up with a working distinction between Child Labor and Child Work. It opined that cognizance must be made of the child's age, the intensity of work and the nature of the industry that engages the child. Towards this end, Child Labor according to ILO comprises all Children between 5-9 years of age who engaged in economic activities and children between 10 14 years who engage in economic activities for more than 14 hours per week. More so, Child work are all productive activities carried out by children lasting over 1-hour duration per day. This could be formal or informal, remunerated or non-remunerated, part-time or full time, family enterprise or common market (Adonteng-Kissi, 2018). The ultimate aim of Parents who sponsor their children for child labour is that everybody counts in poverty reduction in the Family. Children are then canvassed to contribute their productive activities toward the generation of additional income to reduce family poverty level.

\section{Research Question}

Towards this end, to what extent is Child Labor a poverty reduction strategy among low-income earners in the state. The study will provide scientific reasoning of examining if any, the inter-relationship between Child Labor and poverty reduction.

\section{Research Objective}

This study, therefore, seeks to examine the quantum effect of Child labour in poverty reduction among low-income earners in Kwara State.

\section{Research Hypothesis}

Ho: Child labour does not have any significant relationship with poverty reduction among low-income earners in Kwara State

\section{REVIEW OF LITERATURE}

Child enrolment may be enhanced by child subsidy, but its impact in curbing child labour remains ambiguous [Ravallion and Wodon (2000)]. Since the main cause of child labour is the poverty of the households, it is sometimes argued that the incidence of child labour can be lowered by higher adult wages [Basu (2000)]. The government may intervene in the market to curb child labour, but its success largely depends on how this intervention takes place (Basu, 2000).

For instance, Dessey (2000) has argued that compulsive measures meant for elimination of child labour can sometimes be justified when incentives and regulations are combined. Children that are engaged in child labour often faced one form of health or physical abuse at one point or the other. Some of them are even lured into armed robbery and thuggery. Scholars among whom are Aderinto (2000), Charles and Charles 2004 and Agu (2015); believed that child labourers face robbery, inadequate rest and sleep, stress and 
irritability, personality disorder and other anti-social behaviours.

\section{Cultural Relativism}

Hardly is there any known template that will give a general definition of what child labour is all about. There is no universal declaration or cultural relativism of what child Labor is all about. Hence, there is no universal template to compare one culture to another (James and James, 2012). Cultural relativism is a vibrant and dynamic phenomenon that changes from time to time and from culture to culture (Pityama, 2002). This then will make it difficult to give an acceptable and generalized definition of what child labour is all about. Hence, scholars among who are Van der Vyer, 2001. Donnelly (1984) and Rentein (2013) were all of the opinions that universal human rights and standard are purely western ideas that should not be taken as universal rule and tradition. Specifically, African culture and background are different from those of the Europeans. There is no relativism among the diverse cultures of the world.

Children are often engaged in various kinds of labour in Nigeria. Past studies have shown that child labourers' in Nigeria involved in all sorts of child labour activities such as hawking, begging, load carriers, farming, quarrying and prostitution. This has led to health and educational problems ranging from injuries, pains, traffic accidents, chemical poisoning, pneumonia and the likes. Many factors have been advanced as causative factors of child labour in the country. These among others are poverty and high rate of unemployment, lack of adequate access to education, inadequate and non-enforcement of laid down rules and regulation regarding child schooling and employment.

Increased access and higher returns to education, changes in social norms, a shift in production from predominately agricultural to manufacturing, and developments in political and legal institutions may all contribute to a reduction in child labour. (Bassey et al. 2012); Kadiri (2011). Therefore, an analysis of the relationship between poverty and child labour is likely to yield more relevant results when undertaken at the household level, where it is possible to distinguish between household characteristics and broader macroeconomic considerations.

\section{Educational System In Nigeria}

The Nigeria education system can be decamped into three different sectors (WES Staff, 2017). Nine years of compulsory basic education (PRY 1-6 and JSS 1-3), three years post basic (SS1-3) and four years tertiary institutions. As of 2015, about $44 \%$ of the countries populations were below the age of 15. This coupled with the lack of will power to invest in education by the various Nigeria government, the shortage of instructional facilities as well poverty resulted into lack of adequate education and deformity in the countries education system. These resulted in drop out of school and searched for funds to insulin the poverty level of Parents by the School Children resulting in Child Labor.

The inability of the government to frontier a functional educational system has led to dire consequences. Lack of adequate job after school has caused many parents as well as the youths themselves to be discouraged in attending schools. Some have searched for jobs while some others 
have joined notorious gangs such as the Boko Haram, cattle rustle and their likes.

\section{Poverty}

Poverty is an economic condition in which people lack sufficient income to obtain minimal levels of health Sciences, Food, Clothing and housing (Kadiri, 2018). Over the years, poverty is often thought of as an economic term but also covers the limited access poor people have to knowledge that addresses their basic human needs and promotes sustainable livelihoods. Towards this end, poverty is also perceived as the relative absence of income, assets, basic services, self-respect, opportunities for education and social mobility and participation in decision making (Ajakaiye and Adeyeye, 2001). The past governments in Nigeria have one time, or the other used different poverty reduction strategies.

\section{THEORETICAL FRAMEWORK Marxian Theory of Poverty}

The theory posits that a poor person is a victim of circumstances resulting from several factors, critical of which is the production system. Karl Marx points out that the entrepreneurial practices of the owners of means of production (capitalists) to move away from labour to capital intensive means of production to boost production and increase profits led to massive unemployment which often later result to poverty. If people are poor, it reduces their demand capability which on the long run results into large unsold stocks of the company. The resultant effect of lack of demand for company products will lead to downsizing of the labour force, which ultimately leads to reduction (unemployment) and poverty.

\section{Cultural Theory of Poverty}

This theory was developed by Oscar Lewis in 1968 and built on the Marxian theory of poverty. It posits that a continuous rise in unemployment due to organizational downsize driven by the capitalists' quest for improving means of production and profitability will lead to the emergence of more downtrodden (unemployed) paupers. The paupers collectively group up into a specific geographical environment or class. The grouping can emerge as a result of either institutionalized government welfare programmes or the set-up of formal national boundaries such as districts or provinces for effective governance of this category of people.

The Social Democratic Theory of

\section{Poverty}

This theory was advanced based on experiences in Britain in the 1920s. The theory assumes that poverty is a class-based concept, and it comes about due to class struggles in society and not based on means of production. Piero Sraffa who advanced this theory argued that class struggles went beyond production spheres and therefore restricting poverty explanations to productions means as was the case in Marxian and cultural theory of poverty would be limiting the scope needed to understand poverty. The politics around how goods and services are produced and distributed affects poverty, just like the means of production used.

The Darwinist Theory of Poverty Poverty is a self-inflicted situation according to the social Darwinist theory of poverty and so it evolves over time as a result of social 
evolution. An individual's excellence or mediocrity will naturally cause that individual to be poor or otherwise. Poverty is therefore "both a final judgment and a purgative by which society selectively eliminates the unfit". Poverty trends in any society is as a result of natural selection and therefore any man-made attempt to change the course of the trend leads to impairment on the natural functioning of institutions (Harvey \& Reed, 1992:286). Social Darwinist theory of poverty identifies two types of poverty based on studies in the urban areas. The First type is normal-class poverty which is a correctable situation caused by social and ecological developments that take place in urban areas. Normal-class poverty is manifested through physical handicaps, old age or female headed household with dependent children. Normal-class poverty is self-correcting since if focuses mainly on income based poverty. It can be eliminated when an individual attains maturity or moves from one economic class to another or is assimilated. Other methods of elimination include education and training or natural evolution of the urban area. This study shall be based on the social darwinist theory of poverty since it is the related to the focus of the discussion. This is because the theory is premised on rural areas which is the focus of this research work.

\section{Empirical Framework}

The incidence of child labour is very high in Pakistan, where, according to the Child Labour Survey, 1996, there are an estimated 3.3 million working children between the ages of $5-14$ years. Even though child labour is often harmful to the children, there are situations where its alternatives may offer even deeper poverty both for the children and their families. It is commonly believed that child labour often comes at the expense of child schooling.

Burki and Fasih (1998) and Burki and Shahnaz (2001) and Ray (2001) used data obtained from the Pakistan Integrated Household Survey as well as child labour survey. They discovered that child labour does not reduce the poverty level of household in Pakistan. However, there was a wide range variation in the use of a child as labour between the urban as well as the rural areas.

Bassey et al. (2012), in a similar study using the Calabar Municipality, carried out a similar study with 125 respondents. The study posited that child labour is often a resultant effect of the unfavourable socio-economic environment. The study, therefore, declared that on the long run, the resultant effect of child labour would be negative economic probabilities such as a reduction in national income and insecurity.

\section{METHODOLOGY}

A survey design was employed because of the study involved in eliciting the opinions of people living in the state. A pilot study was first carried out through a focus group discussion as well as direct interaction with the parents/guardian of the child labourer. A detailed questionnaire was subsequently administered. The researchers used a purposive sampling method to select the respondents from the 3 Senatorial districts of Kwara state. A total of 650 respondents were selected from the three Senatorial districts. 
Due to its population as well as the centrality of the district as the state capital, Kwara Central had 350 questionnaires distributed among the respondents.

In comparison, the remaining districts (Kwara North and South respectively) had $\quad 150$ questionnaires each administered on the respondents. Research assistants were engaged in interpreting the questions to the respondents and also assisted in administering the questionnaire. The Chi-square $\left(X^{2}\right)$ method of data analyses was then used to analyze the data obtained.

\section{DATA AND INTERPRETATION OF RESULT}

This study observed that there are more females in the child labour business than their male counterparts. A total of $42 \%$ of the male were into child labour while the female represents $58 \%$. More so, 94 male representing 35\% assist in the family business while $64 \%$ of female were involved in the family business. Majority of the ladies have had one form of sexual abuse or the other from their bosses or opposite sex.

Table 1:

\begin{tabular}{|l|c|c|c|}
\hline $\begin{array}{c}\text { Category of } \\
\text { respondents }\end{array}$ & Poverty reduction & Schooling & Total \\
\hline $\begin{array}{l}\text { Child labour for } \\
\text { poverty reduction }\end{array}$ & 255 & 136 & 31 \\
\hline Family work & 170 & 89 & 259 \\
\hline Total & 425 & 225 & 650 \\
\hline
\end{tabular}

Source Authors' Field Survey (2020).

Using the $X^{2}$ formula

$X^{2}=\frac{(O-E)}{E}$

Where 0 indicates the observed frequency and $\mathrm{E}$ the expected frequency (Beri, 2008).The expected frequency is thus obtained by using $\mathrm{E}=$ row total $\mathrm{x}$ column total Grand total

Table 2:

\begin{tabular}{|l|c|c|c|}
\hline \multicolumn{1}{|c|}{$\begin{array}{c}\text { Category of } \\
\text { respondents }\end{array}$} & Poverty reduction & Schooling & Total \\
\hline $\begin{array}{l}\text { Child labour for } \\
\text { poverty reduction }\end{array}$ & $391 \times 425 / 650=255.7$ & $391 \times 225 / 650=$ & 391 \\
\hline Family work & $259 \times 425 / 650=169.3$ & 140.8 & \\
\hline
\end{tabular}

Table 3

Source: Authors' Computation, 2020

Obtaining our $\mathrm{X}^{2}$, we have;

\begin{tabular}{|c|c|c|c|cc|c|}
\hline Row & Column & $\frac{\text { Frequency }}{0}$ & $\frac{\text { Frequency }}{O}$ & O-E (O-E)2 & $\frac{(0-E)^{2}}{E}$ \\
\hline 1 & 1 & 255 & 155.7 & -0.7 & 0.49 & 0.0019 \\
\hline 1 & 2 & 136 & 140.8 & 14.8223 .04 & 0.16 \\
\hline 2 & 1 & 170 & 169.3 & 0.7 & 0.49 & 0.0029 \\
\hline 2 & 2 & 89 & 87.7 & -0.7 & 0.49 & 0.0055 \\
\hline \multicolumn{7}{|c|}{ Total } \\
\hline
\end{tabular}

Source: Authors' Computation, 2020 
A $2 \times 2$ table will take a degree of freedom of $(r-1)(k-1)=1$ at both $5 \%$ level of significance, $X^{2}$ is 3.84 . While $X^{2}{ }_{c}$ is 0.17 . since the $X^{2}{ }_{t}>X^{2}$, we accept the null hypotheses that there exists a relationship between child labour and poverty reduction. We reject alternative hypotheses.

\section{Discussion of Findings}

It was observed that 63 per cent of the female in the child labour business had been sexually abused or raped at one point or the other. It is only 11 per cent of the male counterparts have at one time or the other been abused sexually. A total of 36 per cent of the child labour combine work with the schooling of this category, 13 per cent were boys, while 24 per cent were girls.

From the study, only $12 \%$ of child labour said there never had any negative health implications in the last 1 year. Most of them have had one form of negative health effect or the other.

\section{CONCLUSIONAND}

\section{RECOMMENDATIONS}

\section{Conclusion}

This study has explained that child labour is predominant in Kwara State. It is evident from the proportional children in the state and those that are enrolled in schools (both western and Islamic schools). The low-income earners are the most vulnerable often in their unregulated family size. The resultant effect has been a high rate of insecurity, rate, thuggery, rituals, drug abuse and its likes.

The government, both at the federal and state levels are yet to live up to their expectations. They make lots of promises in their political campaign without implementation. The inability of the government to provide jobs for graduates have discouraged most of the children to have interesting schooling. Rather they support their parents to engage in one form of child labour or the other. The current state of school infrastructure is not something to write home about. The introduction of 6-3-3-4 system of education without the corresponding infrastructure have led to the demise of the system even before its commencement. Most of the money budgeted for these activities are either diverted or embezzled. The rate and pattern of corruption in the country are now unpredictable.

\section{Recommendations}

a. The government should provide adequate job opportunities for all its citizens to improve the economic conditions of the lowincome earners.

b. There should be a potent economic environment that will encourage those with genuine ideas to engage in promising economic activities. This will lift a lot of low-income earners to higher pedigree.

c. Parent/guardians in the lowincome groups should be encouraged that extra efforts in assisting their children not to engage in child labour but schooling as a future investment with a higher rate of return.

d. The government can provide free specialized schools that are adequately funded to assist the children of the low income and disadvantaged parents.

e. Parents and teachers should do a follow-up on children that are absent in school. 


\section{REFERENCES}

Aderinto, A. A. (2000). Social correlates and coping measures of street-children: a comparative study of street and nonstreet children in south-western Nigeria. Child abuse \& neglect, 24(9), 1199-1213. Adonteng-Kissi, O. (2018). Causes of child labour: Perceptions of rural and urban parents in

Ghana. Children and Youth Services Review, 91, 55-65.

Adonteng-Kissi, O. (2018). Parental perceptions of child labour and human rights: $A$

comparative study of rural and urban Ghana. Child abuse \& neglect, 84, 34-44.

Agu, O. C. (2015). Child Labour and Economic Development In Nigeria-A Case Study Of Ekiti

Economic \& Management State, Nigeria. Journal of Perspectives, 9(4), 27.

Ajakaiye, D. O., \& Adeyeye, V. A. (2001). Concepts, measurement and causes of

poverty. Central Bank of

Nigeria Economic and Financial Review, 39(4), 8-44.

Basu, K. (2000). The intriguing relation between adult minimum wage and child labour. The

C50-C61.

Economic Journal, 110(462),

Burki, A. A., Fasih, T., \& Din, M. U. (1998). Households' Non-leisure Time Allocation for

Children and Determinants of Child Labour in Punjab, Pakistan [with Comments]. The

Pakistan

Development

Review, 899-914.

Burki, A. A., \& Shahnaz, L. (2001, October). Implications of Household Level Factors for
Pakistan.

Children's Time Use in Conference on Child Labor in South Asia, New Delhi (pp. 15-17).

Dessy, S. E. (2000). A defense of compulsive measures against child labor. Journal of

Development

Economics, 62(1), 261-275.

Donnelly, J. (1984). Cultural relativism and universal human rights. Hum. Rts. Q., 6, 400.

Ravallion, M., \& Wodon, Q. (2000). Does child labour displace schooling? Evidence on behavioural responses to an enrollment subsidy. The economic journal, 110(462), 158175.

Renteln, A. D. (2013). International human rights: universalism versus relativism. Quid Pro

Books. 